\title{
Libraries in the Jewish Settlements in Argentina
}

\author{
Irene Münster \\ University at Shady Grove
}

\begin{abstract}
In the late nineteenth century and beginning of the twentieth century, Jewish immigrants took, when possible, from the Russian empire to their new destinations their dearest possessions. One of these was their books. Religious and prayer books represented the knowledge sages and rabbis had passed from generation to generation to their people. Belle lettres and political books in different languages were an important part of their education, upbringing, and ideology. These collections were the start of the libraries at the Jewish settlements in Argentina. Based on published memoirs of these first settlers this article presents how these libraries were created and notes a pattern of similarities on how they became a space to share books, to socialize, to enjoy cultural events, including readings and discussions of Yiddish and European masterpieces as well as musical and theatrical evenings, and to promote political beliefs.
\end{abstract}

KEYWORDS: Jewish libraries, Argentina, libraries, Jewish Argentinean colonies

\section{Introduction}

Whenever people start their migration journey, whether because of persecution, intolerance, economic privation, or other reason, they need to decide which of their possessions to take and which to leave behind. The process of uprooting, as difficult as it is, does not mean immigrants erase their past and start anew in the country that welcomes them. Taking with you some soil, religious artifacts, paintings, or books is a way to be at home in a new place.

For centuries, during times of persecution and expulsion, Jews have taken with them treasured religious artifacts such as Kiddush cups, candleholders, and Torah Scrolls. Befitting a group often called the People of the Book, they have also taken large numbers of books both religious and secular. Their religious books contained the knowledge sages and rabbis had passed from generation to generation to their congregants. The sacred books taught them customs and rituals, how to behave and worship. Belles lettres and political books were also an important part of their education, upbringing and ideology.

Libraries: Culture, History, and Society, Vol. 2, No. 2, 2018

Copyright @ 2018 the American Library Association's Library History Round Table 
This article will focus on the Eastern European Jews who emigrated to Argentina at the end of the nineteenth century and the literary culture they transferred from their homelands and sustained in their new home. Libraries were vital parts of almost all Jewish communities in Argentina. They became spaces in which to share books, to socialize, to promote political beliefs, and for young people to meet. They became a space where conferences, literary and musical evenings, readings, and debates took place. During this period, several libraries were organized in big cities such as Buenos Aires or Rosario. Buenos Aires offers an appropriate study for libraries founded by immigrant communities with diverse ideologies (anarchists, socialists, and bundists), which have been researched by Bilsky, Dujovne, Garibaldi, Moya, Gutiérrez and Romero, and Tripaldi, among others. ${ }^{1}$ The libraries in the Jewish settlements were initially developed by the immigrant settlers who donated their own books or shared their private collections with their neighbors, or from contributions of organizations. The languages of these books mirrored the languages read by the immigrants, Yiddish, Russian, and other European languages. In time, the libraries were able to purchase new materials, and as the settlers became more familiar with the language of their new home and the younger generation felt a stronger need to assimilate to their new surroundings, the predominant language of library holding shifted from Yiddish to Spanish.

This article, based on published settlers' memoirs, of which there are luckily a fair number, will try to rescue the story of some of these libraries and their librarians in several provinces of Argentina in which Jews settled. These early settlers set an example for future generations on how working together trying to achieve a common goal provided the opportunity of developing cultural institutions that were essential for their Jewish Argentinean identity.

\section{Background}

At the end of the nineteenth century pogroms and anti-Jewish riots broke out in cities and towns throughout the Russian empire. ${ }^{2}$ The resulting plunder, destruction, and murder of Jews marked the beginning of the mass emigration movement to Palestine, Western Europe, and the Americas. It is estimated that, from I870s to I9I7, some 3 million Jews abandoned Russia, Poland, Ukraine, and Rumania in large numbers to look for better life opportunities. In time, the Jewish Colonization Association (JCA), founded in I89I by the German Jewish philanthropist Baron Maurice de Hirsch, encouraged the creation of Jewish settlement in rural areas outside Europe. ${ }^{3}$ The main current streamed to Canada 
and the United States, though restrictive laws in the I920s eventually ended largescale Jewish emigration to the United States.

Another, increasingly significant destination for Jewish emigrants from Eastern Europe and Russia was the Republic of Argentina. ${ }^{4}$ Argentina had long suffered from a shortage of agricultural labor and had tried to attract immigrants. In 1854 the Argentinean government allocated significant financial resources to encourage European immigration by giving newcomers special privileges. In I88I, during the presidency of Julio A. Roca, a decree was issued which appointed a special representative to attract Jewish immigrants, specifically inviting Russian Jews to settle in the country. ${ }^{5}$ This was a turning point for Jews trying to find a new home.

The JCA acquired land of varying quality in different provinces in Argentina for Jewish settlement. The JCA provided immigrant families with passage to Argentina and, upon landing, with a parcel of land, tools, animals and seed to work the arid, never-plowed soil that had been assigned to them. The settlers, most of whom had no previous agricultural experience, had to pay back the JCA for that support. ${ }^{6}$

These colonists created a number of new settlements in the provinces of Buenos Aires, Entre Ríos, Santa Fe, Santiago del Estero, and La Pampa, which were some of the more fertile provinces in the country. Settlements in Chaco and Río Negro provinces were personal initiatives of Jews in which the JCA had no intervention. The colonies and the villages that grew up around them reached their peak in the I930s. Farm-based industries were developed, and craftsmen settled in these villages. During that decade the worldwide depression led many younger members of these communities to seek opportunities in Argentina's cities, leaving many of the older settlements to decline. The settlers' lives were not easy; hunger, disease and overcrowding were some of the reasons why one of the first things these immigrants built were cemeteries. The colonists faced natural calamities such as drought and locusts, which struck the colonies regularly, on top of having to contend with a new culture and language and the remoteness of their farms from railroad stations and markets. $^{7}$

But along with cemeteries, the settlers also built schools and synagogues. ${ }^{8}$ They wanted to preserve their faith, traditions, and customs and transmit them to their children. Close family ties were maintained, and marriage outside the communities was rare. Education played a key role in settler communities since promoting knowledge offered the possibility of a better future and attracted those who craved cultural improvement. The JCA created elementary 
Jewish Settlements in Argentina

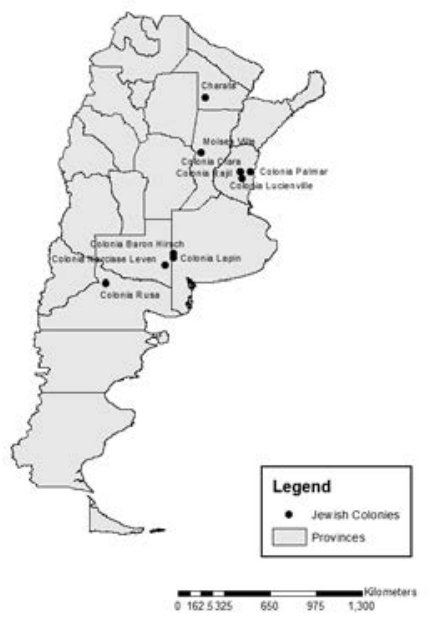

Figure 1 Caption TBA

schools; significantly, the schools were coeducational, providing girls as well as boys the opportunity to study. The lack of trained teachers among the settlers necessitated the hiring of Sephardic Jewish teachers ${ }^{9}$ from the Alliance Israelite Universelle (AIU), created by Adolphe Crémieux in I860. These teachers, who arrived in the colonies between 1890 and 1915, knew French, Ladino (a romance language derived from Old Spanish), and/or Spanish, but not Yiddish. ${ }^{10}$ During those first years children were bilingual, speaking the language of their parents at home and Spanish at school or when interacting with immigrants from other European countries and criollos. ${ }^{11}$ Instruction was divided, with parents providing religious instruction and the AIU teachers teaching secular subjects in compliance with state school requirements. Schools were built for every Ioo rural families, but some schools were remote and not easily accessible.

\section{Findings}

It was clear to the settlers that literacy and access to education played a role in their chances for success, and it soon became clear that libraries were essential adjuncts to education. Thus, children's libraries were created in several settlements. At first the schools consisted of a single room, which also served as a home for the teachers. In short order, the settlers added a library to the room, 
or built an adjacent storage area for Yiddish, Russian, Hebrew, and Spanish books. In I9I3 Salomon Resnick, a Spanish teacher in one of the JCA schools in Narcisse Leven colony, became its school librarian. ${ }^{12}$

These libraries typically subscribed to Hebrew-language newspapers such as Ha-Melitz, published first in Odessa, and Ha-Zefirah, published in Warsaw, which kept the colonists informed of events in their homeland. To learn about news in their new country, they read the publications from the big cities such as Odessa and Warsaw, as well as Buenos Aires' Yidishe Zeitung (1914) and Di Presse (1918) and Yiddish newspapers that sprung up in various Argentinian settlements, including Der Yidisher kolonist in Argentine (Clara, 1909), Der Fateidiguer (Mauricio, 1912), Der Onfang (MoisesVille, 1913), Riverer Wojenblat (Rivera, 1916), Di Pampa (Rivera, 1918), El Alba (MoisesVille, 1918), Entre Rios Tribune (Basavilbaso, 1928), and Der Aker (Narcisse Leven, 1933). Most settlers participated in one way or another in the numerous political, social, and cultural activities available. Their interests were reflected in the creation of libraries, periodicals and newspapers, theater groups, choral groups, agricultural co-operatives, hospitals, and political parties.

Some immigrants brought with them their religious books; others brought books or materials to promote their political ideals. They were able to save these from the pogroms that wiped out their villages. Few immigrants were illiterate; they usually knew Yiddish and at least one other language (Russian, German, Ukrainian, Polish, or Hungarian). The creation of libraries with activities organized around reading books, discussing literary masterpieces in Yiddish or other languages, and enjoying musical and theatrical evenings was an easy step for them to take. In some libraries, the settlers organized formal literary debates and political lectures promoting a wide range of belief. Máximo Yagupsky, community leader and writer, recalls how writers used to read their works to appreciative audiences. ${ }^{13}$ At first, libraries were organized in private homes, in schools or synagogues, until sufficient funds were obtained for a separate building. According to Isaac Kaplan, pioneer of the agricultural cooperatives and veteran in the South American Zionist movement, the young settlers were the ones who dedicated their spare time to create libraries since that was a space where they were able to meet, learn Spanish, hold political debates, or even dance, but mainly to interact and have a space for themselves. ${ }^{14}$ Some of these colonies came to have many libraries; Colonia Clara at one time boasted seventeen libraries, some of which were in private homes. ${ }^{15}$

In 1907 the JCA decided to offer financial support to libraries provided they were administered by the settlement cooperative or other organization 


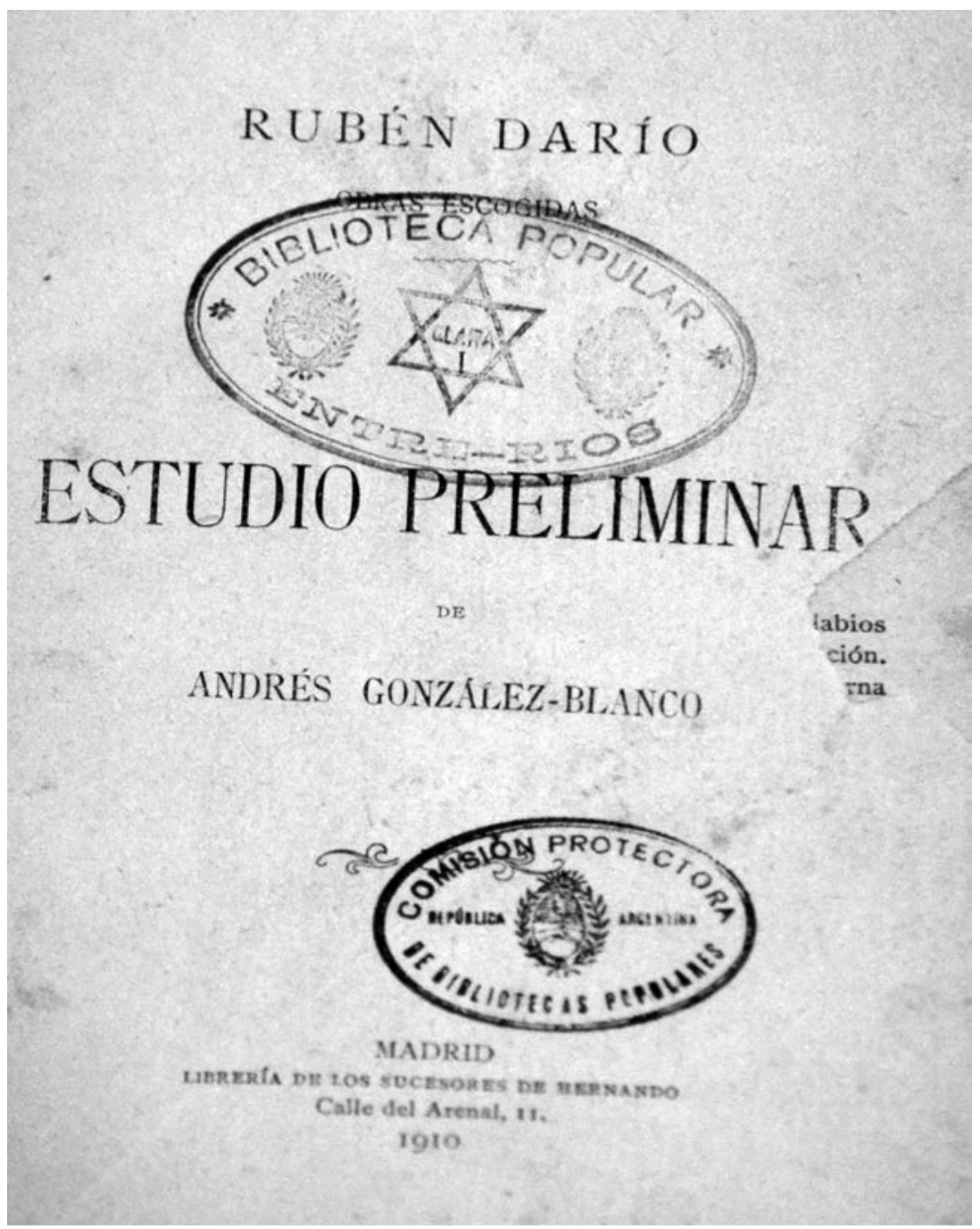

Figure 2 A book of the colonies with different libraries stamps. (Photo courtesy of Alberto Sedler.)

under the supervision of the settlement administrator. The JCA subsidized the purchase of books by matching funds provided by settlers up to 500 pesos. Its goal was for settlers to purchase books dealing with agriculture in order to learn how to improve their skills and ability to work the land. During the Jewish holidays plays were presented in many places to raise money for books. 
The arrival of Jewish settlers in Entre Ríos province, the main site of the JCA agricultural settlements, resulted in an invaluable cultural contribution that transformed the way of doing business. Entre Ríos became the cradle of Argentinean agrarian cooperativism. The Cooperativa Fondo Comunal (Community Fund Cooperative), under the leadership of its president Miguel Sajaroff, pioneer of agrarian cooperativism in Argentina, decided in 1908 to set up the library in the town of Domínguez. ${ }^{16}$ The library still bears the name of former Argentinean president and educator Domingo Faustino Sarmiento. ${ }^{17}$ The library started operations in the old Hotel de Inmigrantes (Immigrant Hotel) warehouse, which was used as a social gathering space known as Club Social Baron de Hirsch (Baron Hirsch Social Club). In 1929, with the support of the local government, which granted a subsidy for its construction, the library opened with a reading room and social hall. The Cooperativa aimed to create branches in other colonies and to this end asked members for a monetary contribution of two pesos per year. ${ }^{18}$ Libraries were created in most rural communities in Argentina, their management and maintenance carried out mostly by young people.

Isaac Kaplan, from Colonia Lucienville in Basavilbaso, recalls: "Thus began the Jewish colonization: plowing and literature, work and culture." ${ }^{19}$ The first library in Lucienville was organized when several young settlers collected sufficient funds to purchase books from Buenos Aires and abroad. These included works by Mendele Mokher Sefarim, Jizchok Leib Perets, and Heinrich Graetz, which were stored in a small library at a private home. With the growth of the colony and the creation of Primera Sociedad Agrícola Lucienville Israelita (First Lucienville Israelite Agricultural Society), which had as one of its mandate to raise money for the library, in addition to the JCA subsidy, new books were bought for the pleasure of the inhabitants. ${ }^{20}$ In time, the library became independent of both organizations and was renamed Biblioteca Juvenil Israelita (Israelite Youth Library). The library acquired publications in Yiddish and Hebrew and newspapers and magazines in Spanish and also organized conferences and chess tournaments. ${ }^{21}$

In I9II, there existed a library led by the spouse of the administrator in Clara, which had 670 books, " 387 in Jargon, 229 in Russian and 54 in Spanish, French and other languages." 22 Other libraries developed in private homes, including the library of Alter Braslavsky, who was hired as a Yiddish and Spanish teacher for the Novibuco I settlers group, in Lucienville colony. His home was near the school and he set up there a small library, which he also administered. ${ }^{23}$ Moises Chertkoff and his daughters, who tried to teach 
Spanish to children and adults while promoting socialist ideals, organized a library in their home in Colonia Rajil, and Dr. Noe Yarcho, founder of first Jewish hospital in Latin America and the first physician at the Jewish colonies of Entre Ríos, donated his private library to Colonia Clara's library. ${ }^{24}$

Adolfo Banchik, a former settler in Colonia Santa Isabel, recalls that when he was young the settlers used to get together on weekends in different houses to read and discuss books borrowed from the Hathyia library that was part of the Salón Cultural Max Nordau (Max Nordau Cultural Center), which had books in Yiddish and Spanish and operated until 1980. ${ }^{25}$ Dora Bortnik de Duchovny, former teacher at Colonia Carmel, recalls how she created the library Hogar y Escuela (Home and School) in 1924, with the support of the school director and the community. ${ }^{26}$ The library served Carmel settlers as well as Colonia Ida's children, who assisted in Carmel Colony's school. An old wardrobe was set up and packed with books donated by the settlers. Very soon, the library received the benefits of the Comision Protectora de Bibliotecas Populares (Protective Commission of Popular Libraries), which donated Spanish books and provided money for book purchases. ${ }^{27}$ The youth library, named Domingo Faustino Sarmiento, initiated its work as soon as the school was created. Each reader would sign a notebook when borrowing a book and pay a fee of 0.05 cents so that new books could be bought.

Colonia Palmar in Entre Ríos province was founded in 19I2. The following year the settlers built a synagogue and the Sholem Aleichem library. Those involved in its creation visited the settlers in their homes to ask for book donations or for money to buy new titles. Like libraries in other colonies, the Sholem Aleichem library became a gathering place where people met and organized reading circles, exchanged books, and had literary discussions. ${ }^{28}$

In the southwest of the Buenos Aires province, Colonia Baron Hirsch, now Rivera, was set up in 1906 when several families from Novy Bug, Ukraine, decided to create an independent colony and requested funds from the JCA to purchase land. In 1908 the first library was created and at first sheltered poor Jewish peons arriving to help work the land. Elias A. Marchevsky, its first president, recounts how they reached out to the JCA for help. ${ }^{29}$ The community sent a list of books they were interested in purchasing, but the JCA rejected most of those on the list, including works by Emile Zola, Karl Marx, Leo Tolstoy, Fyodor Dostoyevsky, and Mendele Mokher Sefarim. The library's board had to turn directly to publishers and bookshops to obtain them. The library received donations of the peons who wanted to contribute to the colony's progress. 
In I9I2, some other young colonists founded the Club de la Juventud Israelita para Recreo y Desarrollo Intelectual (Israelite Youth Club for Recreation and Intellectual Development), better known as Club Juventud Israelita (Israelite Youth Club), and in later years as Centro Cultural Israelita (Israelite Cultural Center). During their first meeting, they decided to build a community center that would include a library. According to Gregorio Verbitsky, members tried to compile a list of titles, 40 percent of which they agreed should be in Spanish, 30 percent in Yiddish, 20 percent in Russian and Io percent in Hebrew. ${ }^{30}$ Spanish books were selected by the school director, the JCA administrator, and L. Dimentstein, while a larger group was assigned to select titles in the other three languages. It is interesting to highlight the intention of these young people to buy so many titles in Spanish and so few in Hebrew. They wanted to adopt the nationality of their new home and to be able to take part in the political and social life of Argentina. The Centro Cultural Israelita's goal was to promote cultural events (readings, performances by visiting artists, and amateur theatrical presentations). ${ }^{31}$ The library sponsored the noche del buzón (night of the mailbox). Discussion topics were written on pieces of paper and deposited in a box. A piece of paper was randomly picked out of the box, and the topic inscribed on it became the subject of a discussion that could last for several hours. These debates occurred at different colonies. The library became a lending library that increased the settlers' ability to read books in different languages and from a number of different cultures.

Rivera was also home to Unión Obrera Israelita (Israelite Union Worker), founded in I9I6 and later known as Centro Obrero (Worker Center), whose members were urban workers (blacksmiths, carpenters, construction workers, and others). In the beginning, their purpose was to promote union activities, but later on they expanded their goal to include mutual aid and cultural activities. At that point, they organized their own library, showed films, and presented plays, and taught evening classes in Spanish and Yiddish.

Both institutions, Club Juventud Israelita and the Unión Obrera Israelita, invited writers to share with the audience their knowledge or organized tributes to writers such as the Yiddish novelist Joseph Opatoshu. Many settlers participated in these activities. After some years, around I9I9 to I92I, the two institutions merged, as did their libraries, which became known as Biblioteca Unida-Unión Obrera y Centro Juventud Israelita (United Library-Labor Union and Israelite Youth Center). On April 3, 1928, by a resolution of the Ministerio de Educación de la Nación (Ministry of Education of the Nation), 


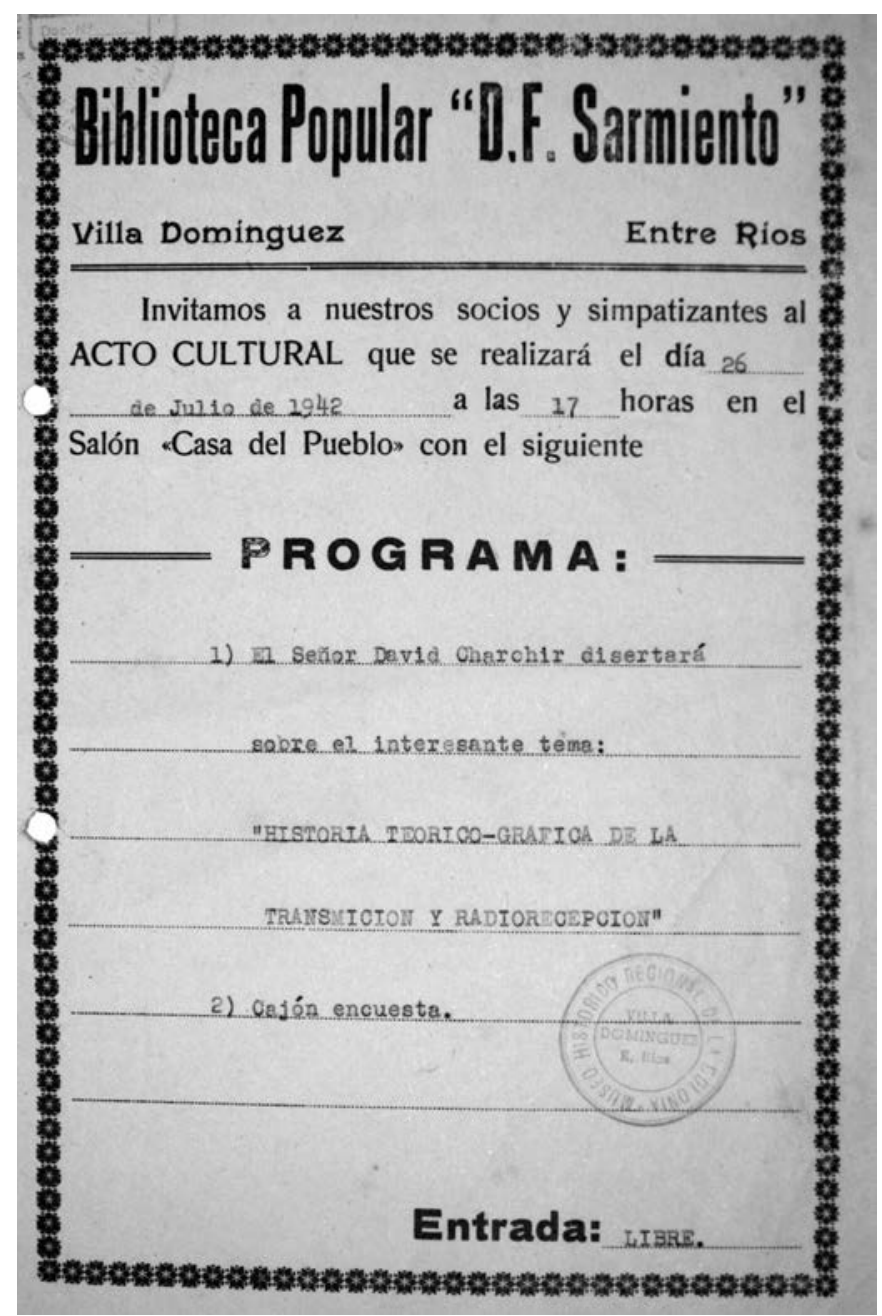

Figure 3 "Domingo Faustino Sarmiento Popular Library" patron "night of the mailbox" suggestion of discussion topic. (Photo courtesy of Alberto Sedler.)

it was declared a biblioteca popular. On June 2I, I93I, a new board decided to name the library after Argentinean physician, philosopher. and essayist José Ingenieros, and it is still known by that name.

In search of better agricultural conditions, in June I9I9 former settlers of Colonia Narcisse Leven established Colonia Lapin in Bernasconi, province of La Pampa. Its first library functioned in a tent until the settlers were able 
to build their homes; it started by providing books to the settlers and slowly evolved into a space for literary discussions, amateur theatrical presentations, and other social and cultural activities. Sometimes it competed with, or shared activities with, Rivera, 45 kilometers away. The library's name was Biblioteca Juventud Popular Israelita de Colonia Lapin (Israelite Youth Popular Library of Colonia Lapin). ${ }^{32}$ Unfortunately, this is one of the libraries that closed when the settlers abandoned the lands for a better future elsewhere.

The young settlers at Narcisse Leven colony, in La Pampa province, planned the opening of a library to share their social and political concerns. They decided that each should contribute five pesos to start the library. The library, named Idische Yuguent (Israelite Youth), began to operate in the estancia La Esmeralda, located in the center of the colony. Very soon the library spread cultural, social, and political activities in the colony and surrounding area. ${ }^{33}$ In 1925, after Yiddish writer Peretz Hirschbein visited the area, the library was renamed in his honor. The library owned some 3,000 volumes in Spanish and Yiddish during its heyday. But with the world economic crisis of 1929-30, which badly affected the Jewish colonies of Argentina, many of the inhabitants of Narcisse Leven left the countryside for cities. So many left that the library had to be closed, and its books were sent to the Idische Folks Bibliotek (Jewish Popular Library) in Bernsaconi town.

In 1920 twenty families set up Colonia Rusa in Río Negro province. In this library, if a borrower could not give adequate proof that he or she had

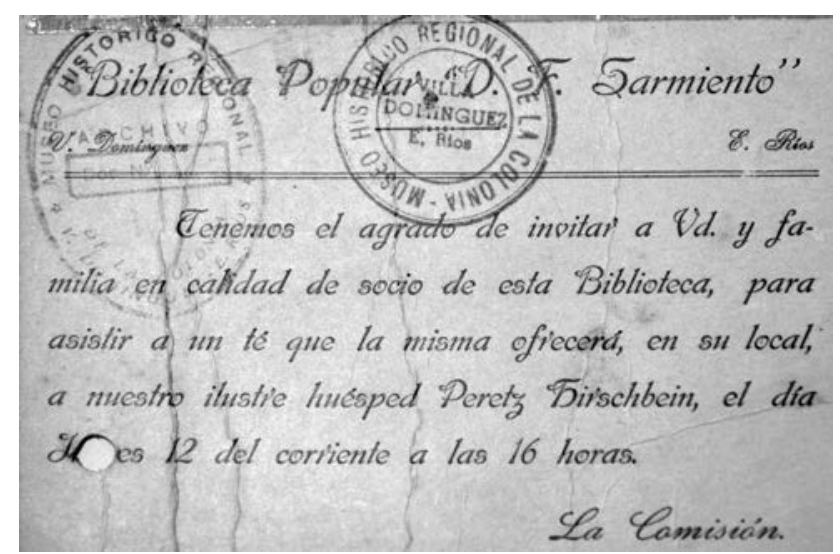

Figure 4 Postcard invitation for members of the libraries to attend a tea time with the illustrious guest Peretz Hirschbein. (Photo courtesy of Alberto Sedler.) 
read a borrowed book when returning it, it was returned to the reader with the expectation the person would read it before returning it a second time. ${ }^{34}$

The anarchist family of Yosl Bursuck originally from the Russia empire, in 1920, moved from Colonia Narcisse Leven to Charata colony, Chaco province, where the family had opened an anarchist bookshop as part of the local business, set up a library named León Jazanovitch in honor of the journalist and editor of Brot un Ere (Bread and Honor) newspaper, who was deported from Argentina after the pogrom of I9Io because of his anarchist affiliation. The library used to lend books and subscribed to various newspapers and magazines. ${ }^{35}$ The Bursuck children and their friends organized a youth library named Brazo y Cerebro (Arm and Brain), where every fifteen days Jews and non-Jews met to discuss literary works and anarchist readings. ${ }^{36}$

Osvaldo Quiroga, the director of the Museum of the Colonies in Villa Domínguez, provides a sense of the importance of the libraries discussed in this article when he notes about the library, "the light radiated by a candle, a small lantern or a kerosene lamp, indicated that in the semi wild surrounding area to the train station Gobernador Domínguez, the mind was cultivated, since the settlers after a long day of hard work in the fields fed not only on Jewish history but began to read and understand Argentinean history, geography, customs and literature." 37

\section{Conclusion}

Jews in Russian and Eastern Europe at the end of the nineteenth century were marginalized, ostracized, persecuted, and restricted in their professions and trades. When faced with the opportunity of starting a new life as farmers most of them were convinced that, once they arrived, they would learn how to plow, plant, and harvest crops. In contrast to Italian or Spanish immigrants in Argentina, who often retained land and maintained strong ties within their homelands, Jewish immigrants had no place to return to. Consequently, their struggle to adapt to the country was in many cases very difficult.

When reading the memoirs or diaries of the settlers, or listening to their recorded interviews, one realizes that almost everyone mentions the creation of libraries, schools, synagogues, and cemeteries as central to their lives in their new communities. Their need to be together as a community and to give their children both an Argentinean education and a Jewish education that would connect them to customs and traditions of their homeland was so important for them that they even deprived themselves of necessities in order to provide 
for them through literary and cultural activities. Through their children, they were able to accomplish their own dreams for upward mobility. Libraries, with their lectures, discussions, and literary evenings, became a vital and integral component of their social and intellectual life.

Each community established a number of libraries, whose direction and upkeep were mostly in the hands of young people. The JCA subsidized their creation to help settlers obtain books that addressed agricultural concerns, and the teachers who taught in the colonies' schools played an important role in the libraries' development. These settlers enjoyed reading and saw in books a vehicle for progress and a means to strengthen their secular, political or religious beliefs.

At first, the books in the libraries were received as donations. This meant that no collection criteria were established until they started to grow. Sometimes a settler was designated to choose books in Yiddish and Hebrew, and another books in Spanish or other languages.

When the young generation started to move to the cities and, consequently, the settlements began to languish, so did their cultural institutions, including the libraries. Parents tended to follow the children as they were unable to work the land in their own. In the long run, those who stayed behind were forced to close the libraries or other cultural institutions. Library books were distributed to other libraries in the settlements or to public libraries in the province or stored in warehouses and forgotten; rodents, the climate, and negligence ultimately destroyed them. Nowadays, it is hard to find any library in the settlements. Documentation on their creation has also disappeared, except for the archives of the JCA that are stored in Jerusalem at the Central Archives for the History of the Jewish People, and the few in Argentina that can be found at the Museo de la Colonia in Villa Domínguez, at the Museo Comunal de Moisés Ville in the province of Santa Fe, and what may be retrieved in Buenos Aires' IWO archives, after a bomb tore it down in 1994.

Libraries were organized as cultural centers and usually served that function. Jewish education played a significant role in maintaining Jewish identity, but the settlers also valued secular education. Older readers were eager to keep on reading Hebrew and Yiddish masterpieces, while increasing the collections of books reflecting newer strains of thought. The young settlers were eager to "belong," to find their place in the country, and schools and libraries became a medium to reach that goal. Libraries in the Jewish settlements in Argentina served the dual function of helping the older generation maintain their traditions and the younger generation assimilate. 
Unfavorable climatic conditions, which resulted in meager harvests, led to the depopulation of the settlements in the I930s. The desire for higher education also prompted settlers' migration to urban areas. The depopulation caused libraries to merge, move, or close. When visiting some of the still-existing settlements one finds books that have been stored in boxes for decades or that have been donated to a public library or museum where current patrons ignore books in foreign languages.

Yiddish writer Isaac Bashevis Singer visited Argentina in 1970 and after his visit wrote the story "The Colony," in which he describes how he gave lectures

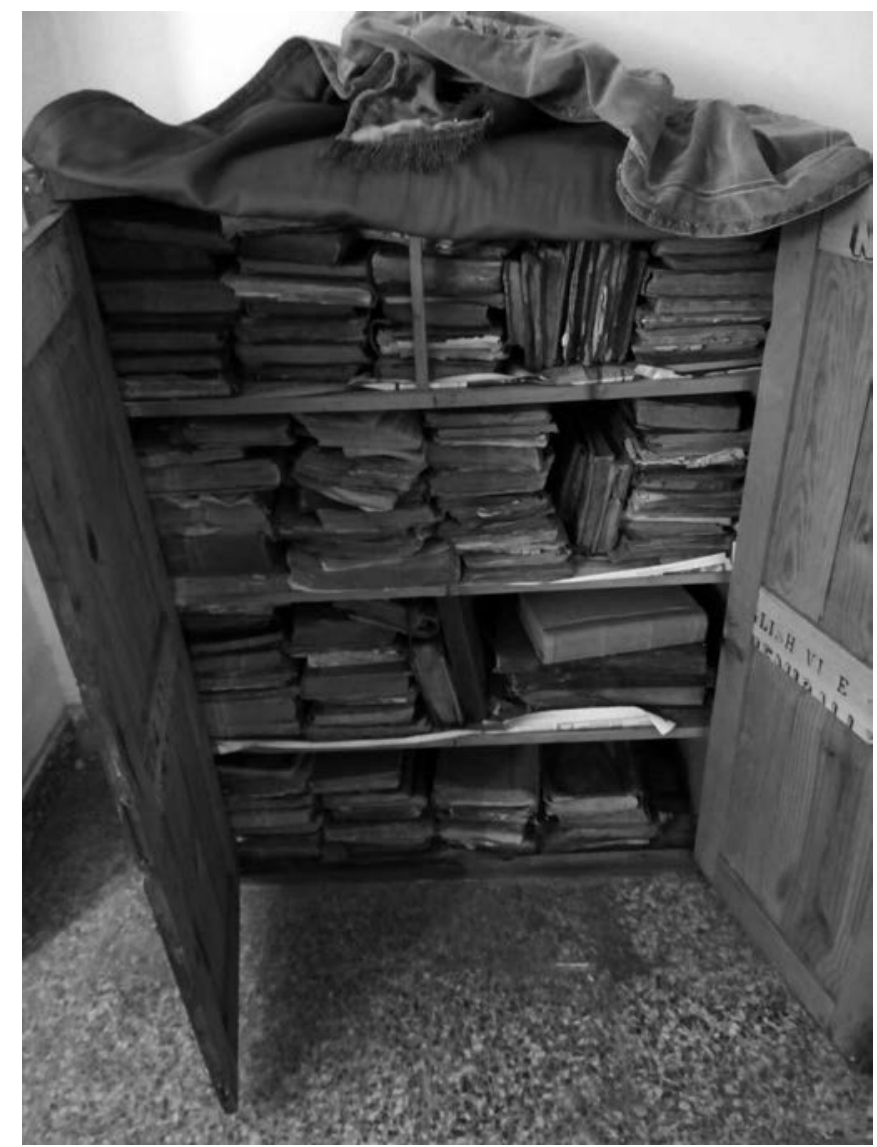

Figure 5 Books stored and forgotten in the General San Martin (La Pampa) community, 2017. (Photo courtesy of Rabi Mariano del Prado.) 
to members of a decaying Jewish colony in Entre Ríos province. Before meeting the settlers, who only read Spanish but no Yiddish, he describes finding a barrel filled with Yiddish books that used to belong to a library and looking at them. When asked what he is doing, he answers, "I am visiting my own grave." ${ }^{38}$ Visiting the existing libraries this is what one experiences.

\section{Directions for Future Research}

There are many other potential avenues for further research. It would be an interesting step to trace the history of some of the books through the library names stamped on them. Another interesting subject to investigate is the librarians: who were they? What was their cultural background? How many were women? Just as important would be to find out the impact the lectures, discussions, or literary events, held by the libraries, had on the settlers and their families. The future challenge is to find the records of these colony libraries to explore how they operated and their active life in the communities they served.

IRENE MÜNSTER was born in Argentina and earned her master of science, library and information science degree at the University of Illinois at Urbana-Champaign, IL. She has worked at several academic libraries before coming to The Universities at Shady Grove (USG). In Argentina she served as library director of the Latin American Rabbinical Seminary and later as library director at the Max von Buch Library, Universidad de San Andres. In the United States she was Bibliographer for Latin America and Iberia and first Jewish Studies librarian at Duke University and then chief of libraries at the Inter-American Development Bank (Washington, DC). She currently serves as director of the Priddy Library at USG, where she provides leadership in the delivery of information services that support the teaching and research of USG community. Münster has been active in several national and international library associations, such as SALALM, AJL, and ABGRA, Library of Congress task groups and IFLA-Argentina. She continues to serve as an informal advisor to Argentine academic libraries.

NOTES

An earlier version of this paper was presented at IFLA WLIC 20I6-Columbus, OHConnections. Collaboration. Community in Session 192-Library History with Library Services to Multicultural Populations. The author would like to thank Eric Lindquist for his editorial help. 
I. Edgardo Bilsky, "Etnicidad y clase obrera: la presencia judia en el movimiento obrero argentino," Estudios Migratorios Latinoamericanos 4, no. II (1989): 27-47; Alejandro Dujovne, "Geografía urbana y palabra impresa. Librerías, bibliotecas e imprentas judías de Buenos Aires," in Una historia del libro judio: la cultura judía argentina a través de sus editores, libreros, traductores, imprentas y bibliotecas (Buenos Aires: Siglo Veintiuno Editores, 2014); Ana Garibaldi, "Bibliotecas de la Ciudad de Buenos Aires y Socialismo: Labor Asociación de Bibliotecas y Recreos Infantiles principios de Siglo XX” (20II), http://hdl. handle.net/I0760/I557I; José C. Moya, "The Positive Side of Stereotypes: Jewish Anarchists in Early Twentieth-Century Buenos Aires," Jewish History I8, no.I (2004): 19-48; Leandro Gutiérrez and Luis A. Romero, "Sociedades barriales, bibliotecas populares y cultura de los sectores populares: Buenos Aires, 1920-1945," Desarrollo Económico 29, no. II3 (1989): 33-62; and Nicolás Tripaldi, "Origen e inserción de las bibliotecas obreras en el entorno bibliotecario argentino: fines del siglo xix y primer tercio del siglo xx," Libraria I, no. I (1997): 22-37.

2. Pogroms were outbreaks of mass violence directed toward Jews that were organized by elements within the government

3. Nevertheless, the JCA did not encourage Jewish mass immigration to Argentina. They preferred to follow a selections process where they identified suitable farmers. Edgardo Zablotsky, "The Project of the Baron de Hirsch. Success or Failure?," CEMA Working Papers: Serie Documentos de Trabajo no. 289, 2005.

4. "Russo-Jewish Emigration to Argentina," Hebrew American, March 30, I894, sec. front page, http://www.jpress.nli.org.il/Olive/APA/NLI/SharedView.Article.aspx?href=HEBAM $\mathrm{C} \% 2 \mathrm{~F}_{18} 94 \% 2 \mathrm{Fo} 4 \% 2 \mathrm{Fo} 6 \&$ id=Aroosor \&sk=EBF2359C.

5. "Decreto nombrando ajente honorario de la República Arjentina, con el objeto de dirijir hácia ella la emigración israelita iniciada en el Imperio Ruso," Pub. L. no. I2OII, 20 39I (I88I). The knowledge Jews from Eastern Europe had about Argentina was mainly from the letters that relatives or acquaintances sent back. Zablotsky, "The Project," I5-27.

6. Argentina's census of 1914 revealed that the population was 7,903,662 inhabitants compared to 3,954,I4I inhabitants in 1895 . Between I9OI and I9I4 some 67,625 Jewish immigrants entered Argentina according to the JCA-Buenos Aires office. Haim Avni, Argentina y la historia de la inmigración Judia: 1810-1950 (Buenos Aires: AMIA, 1983), 536-37.

7. Most of the settlements and small villages or towns were created after the British extended the railway network in 1895 across the region. Winthrop R. Wright, BritishOwned Railways in Argentina: Their Effect on Economic Nationalism, I854-I948 (Austin: University of Texas Press, 1974).

8. According to Avni, 3,538 students attended the 50 JCA schools in I9Io (Argentina $y$ la historia, 275).

9. Teachers were brought from the Magreb countries, Balkans, and other regions in the Ottoman Empire. Diana Epstein, "Maestros de la AIU en las Colonias de la J.C.A.," Toldot 6, no. I6 (March 2002): 4-5.

Io. Gregorio Verbitsky, Rivera: afán de medio siglo (Buenos Aires: Comisión del Cincuentenario de Rivera y sus Colonias, I955), 96. 
II. Criollos are those born in Spanish America but of European, usually Spanish, ancestry. "Criollo," Dictionary, Merriam-Webster Dictionaries, n.d, https://www.merriamwebster.com/dictionary/criollo.

I2. Salomón Resnick, writer, journalist, lecturer, translator from Yiddish into Spanish, and community leader. Founder of Judaica journal. Co-founded the "Hebrew Association" (today "Sociedad Hebraica Argentina") of which he was its first librarian. "Biografía de Salomón Resnick," Judaica, no. 156 (1947): 3-7.

13. Máximo Yagupsky, Entrevista a: Sr. Yagupsky, Máximo, interview by Daniel Bargman, I988, http://coloniasjudiasarg.amia.org.ar/wp-content/uploads/20I4/o4/68-YagupskyI.pdf.

I4. Isaac Kaplan, "La vida social en las colonias," in so años de colonización judía en la Argentina (Buenos Aires: Delegación de Asociaciones Israelitas Argentinas [DAIA], 1939), 219-37.

15. Osvaldo Quiroga, letter to Irene Munster, "Un poco de reseña histórica," April I8, 2016, in possession of author. Colonia Clara was named in honor of the Baroness Claire Bischoffsheim de Hirsch, wife of Baron Maurice de Hirsch. "Baron Maurice de Hirsch (I83I-I896)," Encyclopedia, Jewish Virtual Library, n.d., http://www.jewishvirtuallibrary. org/baron-maurice-de-hirsch.

16. The town of Dominguez was the administrative and distribution center of Colonia Clara (49 villages around Dominguez town). "Villa Domínguez," Circuito Histórico de las Colonias Judías del centro de Entre Ríos, n.d., http://www.colonizacionjudia.com.ar/ dominguez.htm.

17. The library changed its name several times. It was first named "Biblioteca Central de la Colonia," followed by "Club Social Baron Hirsch" in I915, and "Casa del Pueblo" until finally receiving its present name. In 1924 the Biblioteca Domingo F. Sarmiento joined the Federation of Popular Libraries of Entre Ríos, obtaining its legal status. Domingo F. Sarmiento, president from October I2, I868 to October II, I874, founded the first coeducational schools in the country importing normal school teachers from the United States. Osvaldo Quiroga, Biblioteca Domingo F. Sarmiento, interview by Irene Munster, June 20I7, in possession of author.

I8. A. Gabis and D. Merener, Fondo Comunal. so años de su vida (I904-I954) (Villa Domínguez: Fondo Comunal, Sociedad Cooperativo Agrícola Ltda.), 1957, 71. Acta no.59 (junio de 1908).

19. Osvaldo Quiroga, "Museo y Archivo Regional de las Colonias Judías del Centro de Entre Ríos, Villa Domínguez, Argentina," n.d., www.museodelascolonias.com.ar.

20. The Primera Sociedad Agrícola Lucienville Israelita was founded August I2, I900. In I928 the name was changed to Sociedad Agrícola Lucienville. Patricia Boari, Nora Fistein, Antonio Odriozola, Susana Rébora, , and Mario Solari, "Cooperativa Agrícola Lucienville Ltda," Mundo Agrario 8, no. I6 (2008), http://ref.scielo.org/2zgb5x. Regarding the mandates, see Jacobo Glushankov, Basavilbaso en 1932. Colonia Lucienville 370 Aniversario de La Colonización Israelita Homenaje Al Barón Mauricio de Hirsch Con Motivo Del Centenario de Su Nacimiento (Palma de Mallorca-Barcelona, 2004), http://kehilalinks.jewishgen.org/ basavilbaso/pdf/basavilbaso_enı932jacoboglushankov.pdf. 
2I. Ibid., Ioo.

22. Yehuda Lewin, "Bibliotecas y lectores en la aurora de la colonización judía en la Argentina," Judaica Latinoamericana 7 (2013): 173-95. (Jargon might be Yiddish.)

23. Glushankov, Basavilbaso, 33.

24. Three of the Chertkoff sisters married prominent future Socialist party leaders: Mariana Chertkoff, first wife of Juan B. Justo, founder of the Socialist Party of Argentina; Fenia Chertkoff married Nicolás Repetto, an Argentine physician and leader of the Socialist Party of Argentina, and Adela Chertkoff married Adolfo Dickman, a socialist theorist who emigrated from Europe settling with his family in Colonia Clara. In Buenos Aires Fenia Chertkoff founded the socialist Asociación de Recreos y Bibliotecas Infantiles (Association of Recreation and Children Libraries) to take these children off the street, secure for them a safe place, and help them in their studies. Irene Munster, "Spreading Roots: The Origins of Jewish Libraries in Argentina," paper presented at the IFLA World Library and Information Congress 82nd IFLA General Conference and Assembly, August 13-19, 2016, Columbus, Ohio, http://library.ifla.org/I348/I/I92-munster-en.pdf.

25. Susana Chiaramonte, Elena Finvarb, and Graciela Rotman, Tierra de promesas II: las colonias judias del siglo XX en Entre Ríos (Paraná: Dirección Editorial de Entre Ríos, 20II), I52; Yaacov Bayer "Jewish Community in Pedernal (Santa Isabel), Entre Rios Province, Argentina." Beit Hatfutsot-The Jewish Museum of the Jewish People, I996. https://dbs. bh.org.il/place/pedernal-santa-isabel.

26. Dora Bortnik de Duchovny, Recuerdos de una maestra de campaña (Santo Tomé, Sta. Fe, 1980), 33-34, 55-56, 72-73.

27. On September 23, I870, Law number 419, sponsored by Domingo Faustino Sarmiento, gave origin to the Protective Commission of Popular Libraries, with the intention of promoting the creation and the development of libraries with the purpose of spreading the book and the culture. Comisión Protectora de Bibliotecas Populares (CONABIP), Pub. L. No. 4I9 (I870), http://servicios.infoleg.gob.ar/infolegInternet/anexos/45000-49999/48856/ norma.htm.

28. Gregorio Grinberg, Homenaje Hijos de las Colonias-I5-8-89-16-8-89 Buenos Aires-Chaco-Santiago del Estero, interview by USHMM, 1989, https://collections. ushmm.org/oh_findingaids/RG-50.590.004I_05_trs_es.pdf (accessed December 2, 20I7).

29. Elías A. Marchevsky, El Tejedor de Oro: memorias de un colono judio (Buenos Aires, 1964), 79-99.

30. Gregorio Verbitsky, Rivera: Afán de Medio Siglo (Buenos Aires: Comisión del Cincuentenario de Rivera y sus Colonias, 1955), I50.

3I. "Fomentar y desarrollar la cultura argentina, judía y universal y mantener y engrandecer su Biblioteca José Ingenieros.” Postulados del estatuto del Centro Cultural Israelita Elba Nogueria, Gustavo Elman, and David Gornitzky, "Crecer. Boletín Informativo del Centro Cultural Israelita y Biblioteca José Ingenieros,” Rivera: Centro Cultural Israelita y Biblioteca José Ingenieros, n.d., https://www.archivoderivera.com.ar/impresos/crecer_ ain4.pdf, p. 3, and Gregorio Verbitsky, Rivera, I6o.

32. Verbitsky, Rivera, 215

33. Ezekiel Schoijet, "Páginas para la Historia de la Colonia Narcis Leven": (en Adhesión a su Cincuentenario) (Buenos Aires, 196I), 28-30, I27. 
34. Dovy Piflacs, "La Colonia Rusa: Una Colonia Independiente en Cnel Roca," Toldot (2000); Dovy Piflacs, Los Chacareros Judios (Buenos Aires: Deauno.com, 20Io); and Yacob Kaspin, Mi Colonia Rusa: El Relato de la Colonia Judia más Austral del Mundo, Colección Testimonios (Buenos Aires: Editorial Milá, 2006).

35. Sara Itzigsohn, Isidoro Niborski, Leonardo Senkman, and Ricardo Feierstein, Integración y Marginalidad: Historias de Vidas de Inmigrantes Judios en la Argentina (Buenos Aires: Editorial Pardés, 1985), 43, 70-71.

36. Cristina Guzzo, Libertarias en América del Sur: de la A a la $Z$ (Buenos Aires: Libros de Anarres, 20I4), http://www.fondation-besnard.org/IMG/pdf/Libertarias_en_America_ del_sur.pdf (accessed December 2, 20I7).

37. Osvaldo Quiroga, letter to Irene Munster, “Un poco de reseña histórica." in author’s possession.

38. The story was later included in his book, A Friend of Kafka and Other Stories. Isaac Bashevis Singer, "The Colony. A Story," Commentary 46, no. 5 (1968): 57-6I. 